Article

\title{
The Epic of Evolution and a Theology of Sacramental Ecology
}

\section{David C. McDuffie}

Department of Religious Studies, The University of North Carolina at Greensboro, Greensboro, NC 27412, USA; dcmcduff@uncg.edu

Received: 23 January 2019; Accepted: 22 March 2019; Published: 1 April 2019

check for updates

\begin{abstract}
The 'Epic of Evolution' is the scientific story that reveals that we live in an approximately 14-billion-year-old universe on a planet that is approximately 4.6 billion years old and that we are a part of the ongoing process of life that has existed on Earth for 3.5-4 billion years. This article focuses on the religious and ecological significance of the evolutionary epic in an effort to seamlessly connect the ecological value attributed as a part of an understanding of the evolutionary connectedness of life on earth with the Divine grace understood to be present in Christian sacramental worship. With a particular emphasis on the Eucharist, I argue that the sacramental perspective of grace being conveyed through material reality provides the potential for Christian sacramental tradition to make a significant contribution to protecting the threatened ecological communities of our planet. By incorporating William Temple's concept of a 'sacramental universe,' I propose that the grace that is understood to be present in the substances of the bread and wine of the Eucharist points outward so that it can also be witnessed in all of God's ongoing Creation. When the Eucharist is understood as taking place in a sacramental universe from which ecological grace flows; the incarnation can be recognized not as a one-time event but as an ongoing sacramental process through which God is revealed through the perpetual emergence of life. Consequently, as the primary form of sacramental worship in Christian tradition, the Eucharistic witness to the incarnation of God in Jesus and thanksgiving for life overcoming death provide Christians with a ritual orientation for recognizing the incarnational presence of God as an ever-present reality potentially witnessed in all that is. Therefore, the formal sacrament of the Eucharist is a part of a broader sacramental ecology of earthly life in which the presence of Divine grace can be witnessed in all aspects of the natural order. As a result, connecting Eucharistic grace with the value associated with an awareness of the ecological and genetic connectedness of all forms of life serves as a mutual enrichment of sacramental tradition and contemporary efforts to protect life on Earth.
\end{abstract}

Keywords: Epic of Evolution; sacramental theology; Eucharist; ecology; sacramental universe; ecological grace; E.O. Wilson

\section{Introduction}

There is grandeur in this view of life, with its several powers, having been originally breathed into a few forms or into one; and that whilst this planet has gone cycling on according to the fixed law of gravity, from so simple a beginning endless forms most beautiful and most wonderful have been, and are being, evolved.

These are the last lines from the 1859 first edition of Charles Darwin's The Origin of Species in which he developed his theory of evolution through natural selection (Darwin 2006, p. 760). The culmination of Darwin's work on speciation served to illuminate the realization that all living things are connected in one giant web or tree of life that spans millions of years of natural history on Earth. Ironically, Darwin 
had no understanding of the primary biological factor perpetuating this process. The emergence of the science of genetics unlocked this mystery, and in the more than 150 year interval since the publication of Origin, we have been provided with evidence that supports Darwin's brilliant insight. We now know that we are genetically related and ecologically connected to all living things from chimpanzees and bonobos, our closest living relatives with whom we share approximately $99 \%$ of our genetic information, to microscopic bacteria. In brief, all living things on our planet are related through our genetic codes, and it is probable that this genetic kinship can be traced back to the emergence of life's common ancestor, the first single-celled life on Earth. These developments in the biological sciences combined with the sciences of geology and cosmological physics have revealed to us that we live in an approximately 14-billion-year-old universe on a planet that is approximately 4.6 billion years old and that we are a part of the ongoing process of life that has existed on Earth for 3.5-4 billion years. This is the story of the natural history from which we emerged and of which we are inextricably a part, and it is a narrative that is added to on nearly a daily basis by ongoing scientific investigation.

According to biologist E.O. Wilson, a proper understanding and appreciation of this 'Epic of Evolution' is the key to attributing the ecological value that is necessary to protect the world's threatened biodiversity. ${ }^{1}$ In Biophilia, he writes, "I will make the case that to explore and affiliate with life is a deep and complicated process in mental development. To an extent still undervalued in philosophy and religion, our existence depends on this propensity, our spirit is woven from it, hope rises on its currents." Further, he concludes: "to the degree that we come to understand other organisms, we will place a greater value on them, and on ourselves" (Wilson 1984, pp. 1-2). I agree with Wilson on this point, and in the following paper, I will address Wilson's reference to religion's undervaluation of our inextricable connectedness to Nature by exploring the relationship between the scientific narrative of the Epic of Evolution, ecological value, and the sacramental life of the Christian church.

More specifically, I will argue that the sacramental understanding of grace present in the Christian Eucharist can serve as an effective means to perpetuate ecological value for all of life and therefore serve as a valuable contribution to the conservation of the Earth's biodiversity. ${ }^{2}$ By incorporating the concept of a 'sacramental universe' from Anglican sacramental theology, I propose that the grace that is understood to be present in the substances of the bread and wine of the Eucharist points outward so that it can also be witnessed in all of God's ongoing Creation. ${ }^{3}$ Therefore, sacramental grace can potentially become a primary means for the Christian community to value, revere, and consequently care for the natural order.

Connecting the scientific narrative of the Epic of Evolution with a religious understanding of sacramental grace will seem to many to be a bit of a stretch, but I intend to show that not only are a sacramental understanding of Eucharistic grace and ecological value compatible, but also that a sacramental approach to ecology can potentially expand the scope and effectiveness of contemporary efforts to conserve biodiversity. Before moving into a discussion of how the idea of Eucharistic grace can perpetuate the ecological value that emerges from a proper understanding of the Epic of Evolution, let us first further examine the connections between scientific and religious narratives that have been recognized as present in the Epic itself.

1 Wilson is given credit for coining the term 'Epic of Evolution' in his Pulitzer Prize winning On Human Nature, first published in 1978 where he wrote that "the evolutionary epic is probably the best myth we will ever have" (Wilson 1978, p. 201).

2 For the purpose of this article, I will be focusing primarily on the relationship between the transformed Eucharistic substances of bread and wine and the material reality of the natural environment. However, it should be noted that Christian traditions have recognized several dimensions through which Christ's presence can be witnessed. For example, Bruce T. Morrill identifies the following three additional dimensions where the Eucharist contributes to an availability of divine presence: Christ hidden in the faithful, Christ witnessed through the proclamation of scripture, and Christ's leadership through those who minister to word and sacrament in the church. See (Morrill 2012).

3 William Temple referred to a "sacramental universe" in his Gifford Lectures. See (Temple 1951, Lecture 19). 


\section{A Naturalist's Revelation}

I have to admit that I have always read E.O. Wilson as a deeply religious author. It is necessary to clarify that I am not claiming that Wilson identifies himself as such. Wilson certainly makes no such claims but is instead a self-professed secular humanist. In fact, in conversations concerning the relationship between religion and science, Wilson is quite frequently accused by religious critics of being overly reductionistic in his understanding of religion. There is certainly some truth to this criticism given Wilson's claim that religion, as well as ethics, are products of human evolutionary history that served as adaptive traits contributing to the survival of our Homo Sapien ancestors (Wilson 1999, pp. 260-90). Furthermore, he predicts that the "eventual result of the competition between the two worldviews [religion and science] ... will be the secularization of the human epic and of religion itself" (Wilson 1999, p. 290).

Yet, if one pays close enough attention, Wilson's criticism involves a rejection of a particular type of religious narrative, supernaturalistic religious narratives that contradict and claim to compete with the Epic of Evolution. However, he does not necessarily reject what might be called a religious or spiritual orientation. Recognizing the importance of storytelling in human culture, he writes, "People need a sacred narrative. They must have a sense of larger purpose, in one form or other, however intellectualized" (Wilson 1999, p. 289). For Wilson, the traditional orienting function of religious narratives remains, but he wishes to substitute a new, naturalistic narrative that will better orient humans toward a proper understanding of our kinship with all of life. ${ }^{4}$ The awe, beauty, and wonder traditionally associated with religious devotion is maintained but is inspired not by the supernatural but instead by a naturalistic account of the Earth's ecology (Wilson 2012, p. 266).

Therefore, in this sense, the Epic of Evolution, as understood by Wilson, is connected to the function of traditional religious narratives of origin and orientation and is the most proper narrative to help us address the issue of the protection of the threatened biodiversity in our contemporary context. ${ }^{5}$ In his Pulitzer-Prize-winning On Human Nature, first published in 1978, he writes that "the evolutionary epic is probably the best myth we will ever have. It can be adjusted until it comes as close to truth as the human mind is constructed to judge the truth" (Wilson 1978, p. 201). Elsewhere, in describing the religious function of the Epic of Evolution, Wilson writes: "If the sacred narrative cannot be in the form of a religious cosmology, it will be taken from the material history of the universe and the human species. That trend is in no way debasing. The true evolutionary epic, retold as poetry, is as intrinsically ennobling as any religious epic. Material reality discovered by science already possesses more content and grandeur than all religious cosmologies combined" (Wilson 1999, p. 289). We see here, once again, that Wilson's interpretation of the Epic represents both a rejection of and a connection to the function of traditional religious narratives.

However, I believe that the religious significance of Wilson's work is deeper than simply serving as a contemporary scientific alternative for the function of traditional religious narratives. I say this because there is evidence in aspects of Wilson's writings of a clear and profound respect for human spirituality. Furthermore, there are also indications that his work to establish a conservation ethic based on the Epic of Evolution is a continuation, albeit a reinterpretation, of the religiosity of his childhood acculturation. Describing his journey in young adulthood from supernatural theism to a complete devotion to natural history, he states: "I had no desire to purge religious feelings. They were bred in me; they suffused the wellsprings of my creative life" (Wilson 1999, p. 6). In an even more revealing

4 See (Wilson 2012, pp. 287-97).

5 According to Wilson, we have now entered the world's sixth great extinction event, the fifth being the event that led to the extinction of the dinosaurs 65 million years ago, where, if conditions remain the same, half the Earth's known species could either be extinct or seriously threatened by the mid-21st century. With this in mind, Wilson claims that the scientific narrative of evolutionary history is the story that can most effectively achieve the protection of the Earth's biodiversity from the factors that currently threaten it. See (Wilson 2007, pp. 4-5). The causes of this human-induced biological destruction are summarized by Wilson with the acronym HIPPO representing the following ecologically destructive forces: Habitat Destruction, Invasive Species, Pollution, Population, Overharvesting. See (Wilson 2002, p. 50). 
passage from his autobiography, Naturalist, he describes the process by which he drifted away from the Southern Baptist faith of his acculturation and his consequent reinterpretation of grace and its relation to the attribution of value:

The still faithful might say I never truly knew grace, never had it; but they would be wrong. The truth is that I found it and abandoned it. In the years following I drifted away from the church, and my attendance became desultory. My heart continued to believe in the light and the way, but increasingly in the abstract, and I looked for grace in some other setting. By the time I entered college at the age of seventeen, I was absorbed in natural history almost to the exclusion of everything else. I was enchanted with science as a means of explaining the physical world, which increasingly seemed to me to be the complete world. In essence, I still longed for grace, but rooted solidly on Earth. (Wilson 2006, pp. 43-44)

It is in this sense that I feel comfortable referring to Wilson as a deeply religious author. His goal is not to explain away the importance of a religious/spiritual impetus in human culture but to urge that human spirituality should be expressed in a way that recognizes Nature as "vital to our physical and spiritual well-being" and that the "spiritual roots of Homo Sapiens extend deep into the natural world through still mostly hidden channels of mental development" (Wilson 2007, pp. 26, 12). Value or grace, to use his term, emerges from material reality. For Wilson, what emerges from the scientific narrative is a unique form of valuation that results from understanding the complex and intricately connected life on Earth. In his words, "[t]o know this world is to gain proprietary attachment to it. To know it well is to love and take responsibility for it" (Wilson 2002, p. 131). I think it is justifiable to classify such a response as sacramental. It is to this topic that I will now turn.

\section{A Sacramental Ecology of the Eucharist}

The Book of Common Prayer defines the sacraments as "outward and visible signs of inward and spiritual grace, given by Christ as sure and certain means by which we can receive that grace" (2007, p. 857). This definition tells us two things. First, it tells us that the Christian sacramental system is inextricably linked with the life, ministry, and sacramental significance of Jesus. It also tells us quite clearly that, sacramentally, we experience God's grace through material reality. In the Eucharist, this grace is conveyed through the substances of water, bread, and wine. It does not take much of an imagination to expand the understanding of grace conveyed in these material substances to an acceptance that Divine grace is constantly present to us in the natural environment.

In fact, such an expansion of sacramental grace is quite clearly encouraged in the Book of Common Prayer: "God does not limit God's self to these rites; they are patterns of countless ways by which God uses material things to reach out to us" (2007, p. 861). In other words, when we receive the Eucharist as a part of Christian sacramental liturgy, it is not intended as an escape from the world but as spiritual nourishment so that we may be sent back into the world to recognize the grace that is potentially present in all of God's ongoing Creation. We are released from the Eucharistic rite to experience Divine grace in our day-to-day lives in our local environments, that is, in Nature. Consider the words from the post communion prayer in the Book of Common Prayer: "[Y]ou have fed us with spiritual food in the Sacrament of his Body and Blood. Send us now into the world in peace, and grant us strength and courage to love and serve you with gladness and singleness of heart; through Christ our Lord. Amen" (2007, p. 365). If we experience grace in the material substances of the bread, wine, and water present in the Christian sacraments, this grace is not confined within the boundaries of an individual liturgy or the walls of a church community but instead informs those who participate in these sacraments that God's grace can be revealed to us through anything or anyone we may encounter in our Earthly lives. Because value is necessarily applied to any means through which grace is potentially conveyed in the world, the implications of such a view for the attribution of ecological value are clear. 
A prominent example of such a view can be found in William Temple's Gifford Lectures where he refers to the 'sacramental universe' in which we live out our lives. ${ }^{6}$ In other words, if God is the source, center, and end of all material reality, then Divine grace is present to us in all that exists. ${ }^{7}$ Again, Christian sacramentalism is grounded in material reality. According to Temple, Christianity "is the most avowedly materialist of all the great religions" (Temple 1951, p. 478). Therefore, a valuation of the material through the Christian commitment to an incarnational, sacramental view of Divine grace allows this valuation to be extended outward in a manner in which all that exists is potentially sacramental.

What we have here is a distinction between the unique sacraments of the Christian church and a more general form of sacramentality toward which they point. In A Guide to the Sacraments, John Macquarrie describes this extension of the sacramental system to a more generalized sacramentality: "Perhaps the goal of all sacramentality and sacramental theology is to make the things of this world so transparent that in them and through them we know God's presence and activity in our very midst, and so experience his grace." According to Macquarrie, this "general notion of sacramentality ... is not exclusively confined to Christianity but is found in many religions and philosophies" (Macquarrie 1997, p. 1). The significance of such an understanding of sacramentality for the attribution of ecological value is that the conveyers of sacramental grace are no longer seen as "'mere' things, but as bearers of meaning, value and potentiality, as messages from the ultimate mystery we call God" (Macquarrie 1997, p. vii). It is through the acceptance of the broader sacramentality of a sacramental universe that the Christian concept of sacramental grace is seamlessly brought into a relationship with the ecological value inspired though a proper interpretation of the evolutionary epic. In both understandings, what emerges from the inherent connectedness of ecological communities is greater than what can be predicated simply from a knowledge of the biological component parts of these communities. ${ }^{8}$ Regardless of whether it is explicitly attributed with a connection with the Divine, the beautiful mystery of life on Earth inspires a sense of grace, and therefore value, for the natural order.

For Wilson, value emerges from material reality, through an understanding of the natural history of life from which we emerged, and is the source of our physical as well as our spiritual sustenance. This view is perfectly consistent with the broader notion of sacramentality that potentially flows from Christian sacramental tradition. However, if you will recall the Book of Common Prayer's definition of sacrament quoted above, there is also a tension between the uniqueness of a Christian sacramental rite, which is rooted in the history of Christian tradition, and the ecological value toward which it potentially points. This potential discontinuity requires a more careful articulation of the ecological significance of the Eucharistic rite. If one is going to assess the ecological significance of the Christian sacraments, the Eucharist is a good place to start. First, of the seven formal sacraments recognized in Christian tradition, the Eucharist is the one that is observed most frequently. As Macquarrie points out, the Eucharist is "the sacrament of maturity, which the communicant will continue to receive for the rest of his or her life and which will promote spiritual growth" (Macquarrie 1997, p. 102). I have mentioned how an understanding of Eucharistic grace in the substances of water, bread, and wine can be expanded to include a broader sacramentality for the entire natural environment. However, if Christian sacramental worship is going to make a significant contribution to the attribution of ecological value, the ecological value attributed must be considered inseparably related to the Christian tradition of which it is a part. As a result, we must move beyond simply focusing on the acceptance of the basic materiality of the substance of the Eucharist and examine, in a deeper way, the theological

$6 \quad$ See (Temple 1951, Lecture 19).

7 I am borrowing the language of God as the "source, center, and end" of all that exists from Dr. William L. Power, Professor Emeritus at the University of Georgia, with whom I studied from 2004 to 2008.

8 Offering an ecological interpretation of the Aristotelian notion that "the whole is greater than the sum of its parts," Eugene P. Odum, the so-called father of modern Ecology, famously commented that "the ecosystem is greater than the sum of its parts." 
and ritual significance of the sacrament itself. If a connection to the evolutionary epic is considered to be shoehorned into or simply a nice addendum to the sacramental tradition instead of emerging from the very heart of the tradition itself, it will not resonate and will therefore fall short of the potential I am claiming for it. In other words, if there are discontinuities between an understanding of the application of sacramental grace in the Eucharist and the attribution of ecological value, we need to stare them right in the face and not divert our attention for the sake of convenience or upholding an argument we hope to be true.

The Eucharist, perhaps more than any of the other sacraments of the church, represents the potential and tension between the formal sacraments of the church and the broader sacramentality that can potentially lead to a recognition of Divine grace in a sacramental universe. This is the case because the entire Christian theological narrative, the Alph, Chi, Omega of Christian tradition, is contained in the sacramental worship of the Eucharist. Our scriptural tradition begins with a poetic story of Divine Creation in which we are told that all of the created order is endowed with goodness as it is spoken into existence by the Spirit of God. ${ }^{9}$ As Christians, we seek to understand the mystery of the incarnation of this Divine Word, the source of all life, through whom all things come into being. ${ }^{10}$ And, we look forward in hope toward an eschatological fulfillment where Life will ultimately emerge from suffering and death. ${ }^{11}$ These theological concepts lie at the heart of Christian sacramental tradition and undergird the Eucharistic liturgy. ${ }^{12}$ They are also undeniably Ecological in nature. Therefore, the Eucharist orients its participants in the present while allowing us to simultaneously look inward, backward, and forward to discern how the theological concepts of creation, incarnation, and resurrection, which are inherent to the Eucharistic meal and integral to the eschatological hope of Christian tradition, project outward to correspond to the presence of Divine grace in all of material reality. ${ }^{13}$

In relation to the evolutionary epic, this naturalistic interpretation of the Eucharist can be seen as a narrative within a narrative. The Epic of Evolution as described by Wilson is a universal narrative that unites us all, genetically and ecologically, whether we choose to accept this or not. In our pluralistic cultural context, we must recognize that the Christian narrative as represented in the reiteration of the Eucharistic meal is not universal. It arose within the last two thousand years and is a part of a particular human history connected to the larger history of our species, Homo sapiens, that spans approximately 200,000 years. In other words, we can say that Nature is the source for all of the sacraments and therefore necessarily preceded any particular sacramental tradition.

However, there is also a deeper connection between Christian sacramental worship and the 14-billion-year cosmic history of our universe from which life emerged. Although the Eucharist is contained within the larger sacramental ecology of the history of life on Earth and the cosmic history of the universe, it is through participation in the Eucharistic liturgy that Christian worshipers can be ritually made aware of the grace that is present to be experienced in a sacramental universe. In other words, it is the reiteration of sacramental worship that has the greatest potential to point toward an awareness of and appreciation for a broader sense of sacramentality. While the Book of Common Prayer's definition of sacrament as an outward and visible sign of an inward and spiritual grace

9 Genesis 1:1-2:3. Biblical references are taken from (The Green Bible (New Revised Standard Version) 2008) (The Green Bible 2008).

10 John 1:3-4.

11 In his Worship as Theology: Foretaste of Glory Divine, Don E. Saliers describes the emergence of the concept of true eschatology not simply as a discourse on the end times but "as a radical openness to the future." See (Saliers 1994, p. 51).

12 The best way to gain an appreciation for this is to actually read through the prayers and rites of the Eucharistic liturgy. See (The 2007, pp. 316-409).

13 While outsiders may scoff at the seeming supernatural character of religious doctrines such as the Creation, Incarnation, and Resurrection, they represent, particularly understood in relation to the context of the ancient cultures from which they emerged, profound affirmations of the natural order. The Incarnation, which is the ground and inspiration of our theological and sacramental tradition, is a radical statement that God's grace is revealed in physical form. William Temple was referring to the Incarnation when he wrote: "By the very nature of its central doctrine Christianity is committed to a belief in the ultimate significance of the historical process, and in the reality of matter and its place in the divine scheme." See (Temple 1951, p. 478). 
supports a broader sacramentality, it is the unique sacraments of the church which point us outward to worship sacramentally in all of God's ongoing Creation. ${ }^{14}$

Furthermore, Christian tradition has a significant cosmic perspective through the theological understanding that God's grace is incarnate sacramentally through the creative action of the Divine Word in our sacramental universe. Therefore, the ecological value attributed through the Eucharist can be understood as inherent in, instead of extraneous to, the Christian tradition from which it emerges. The very meaning of tradition implies that our faith must be applied anew to shape us in the cultures we find ourselves in, in our contemporary context. Therefore, we need only to reenvision, as opposed to reinvent, our Eucharistic theology to seamlessly connect the concept of sacramental grace to the ecological value that emerges from a proper understanding of the evolutionary history of life on Earth.

\section{Divine Presence and Mystery in Sacramental Grace and Ecological Value}

With this in mind, I now want to turn to the concept of real divine presence in the Eucharist, a concept that undergirds all of the issues discussed in this paper. Real presence in the Eucharist has been interpreted rather broadly; however, for the purpose of this essay, I will focus on the understanding of real presence in the substances of the Eucharistic gifts of bread and wine, which entails an examination of the doctrine of transubstantiation. ${ }^{15}$ I hold that the acceptance of the presence of Christ in the Eucharist, instead of a stumbling block, can be the key that opens to a broader sense of sacramentality wherein participation in the Eucharist can honestly address the issue of connections between sacramental grace and the ecological value related to the narrative of the Epic of Evolution. However, I want to begin with a point of discontinuity related to the doctrine of transubstantiation.

Transubstantiation has long been a stumbling block for Western Christianity, one that contributed to well-defined battle lines during the Reformation and one that is still often highly contentious in current theological discourse. This is due in large part to the fact that the doctrine of transubstantiation was the culmination of the increased emphasis, begun in the 9th century, on the understanding of the gifts of the Eucharistic bread and wine as being transformed into the sacrificial body and blood of Jesus as conveyers of divine grace. ${ }^{16}$ The Fourth Lateran Council (1215) is the first instance of the terminology entering official church doctrine, and it has been continuously confirmed by the official teaching of the Catholic Church to the present. Contemporary criticism of transubstantiation frequently focuses on Thomas Aquinas' use of the Aristotelian categories of 'substance' and 'accident' in his development of the doctrine later in the 13th century to describe the change of substance from the gifts of bread and wine to the body and blood of Christ while retaining the 'accidental' properties of the former. In the space that I have here, I do not intend to provide either a justification for or refutation of the doctrine of transubstantiation or extensively outline the various ways in which contemporary theologians have attempted to mollify its interpretation with modified theologies of real presence. ${ }^{17}$ Instead, I want to provide some perspective on what the doctrine of transubstantiation was intended to achieve and how an understanding of real presence in our contemporary context can be applicable

14 In a discussion on Edward Schillibeeckx's reference to Christ as the 'primordial sacrament,' Macquarrie connects the overall sacramental system of the church with a broader sense of sacramentality as follows: "There is a kind of hierarchy here ... Christ is the sacrament of God; the church is the sacrament (body) of Christ; the seven sacraments are the sacraments of the church; the natural sacraments scattered around the world are, from a Christian point of view, approximations or pointers which find fulfillment in the sacraments of the gospel." See (Macquarrie 1997, p. 37).

15 Concerning the broad understanding of Christ's presence in the Eucharist, Macquarrie writes the following: "The presence of Christ in the eucharist is a multiple presence. Since the eucharist always includes a reading from the Gospel, Christ is present in that word. Since it is Christ himself who presides at the eucharist, he is present also in the human minister, the priest, who rehearses the words and actions which Christ used at the Last Supper. Christ is present too in the eucharistic community, who are made one body with him, so that they dwell in him and he in them. And, of course, Christ is present in the bread and wine, over which have been said his words, 'This is my body', 'This is my blood.'" See (Macquarrie 1997, pp. 126-27).

16 For a more extensive assessment of the debates related to the doctrine of the transubstantiation from the $9^{\text {th }}$ to 13 th centuries, see (Bradshaw and Johnson 2012, pp. 222-27).

17 For a comment on some of these alternative theological perspectives to transubstantiation including "transignification" and "transfinalization," see (Bradshaw and Johnson 2012, p. 341). 
to a theology of sacramental ecology that is necessarily predicated on a scientific perspective of the evolutionary and ecological connectedness of life on Earth.

Contemporary theologians widely criticize grounding belief in Christ's real presence in the eucharistic bread and wine in the Aristotelean metaphysics of transubstantiation as incongruous with how people today experience and reflect upon ritual and symbol in relation to the wider reality of their lives. However, to dismiss the reality of real presence in the Eucharist along with outdated metaphysical concepts associated with transubstantiation risks limiting a deeper understanding of the development of the concept of real presence in Christian history as well as the significance that such a doctrine potentially has when lived out in the world by the Christian community. For example, referencing the importance of recognizing the real presence of Christ in the Eucharist, David Brown defends Aquinas claiming that he "sought to defend that basic conception but in a way that excluded crude physical consumption" (Brown 2007, p. 410). Such a corrective defense was surely needed in Aquinas' time to counter the prevalence of a literalist interpretation of the consumption of the body and blood of Christ at the Eucharistic meal. ${ }^{18}$ For Brown, what is essential is that we continue to identify with the bodily presence in the Eucharist since we encounter Eucharistic grace through material reality, both in terms of the substances of bread and wine but also in relation to our own bodies that take in these gifts with the faithful confidence that God's saving grace is mediated in some mysterious way through them. Our recognition of the bodily kinship that all life shares with Jesus is something that Brown fears we have failed to properly emphasize in our contemporary theological conversations. He writes:

It is only really in the modern world that understanding of Christ's presence has moved primarily towards conceiving of it in terms of a presence within the gathered community or else as some sort of rarefied personal presence, essentially no different from the ubiquity of divinity. Transubstantiation is, admittedly, by any reckoning an implausible use of Aristotelian metaphysics. It did, however, have the merit that it thereby preserved some sense of it being important that we relate to Christ as having had and continuing to have a bodily identity like our own. (Brown 2007, p. 390)

Therefore, this is not simply a reiteration of the traditional doctrine of transubstantiation but a commitment to the significance of the real presence of Christ in the Eucharist in our current sacramental worship. The theological concept of transubstantiation is still useful, not in terms of defending its doctrinal formulation but in the sense, according to Macquarrie, that it "has come to stand for the view that there is in the eucharist a real abiding presence of Christ as against any view that denies this" (Macquarrie 1997, p. 131).

Brown's insistence that we recognize the bodily presence of Christ is important not only because it affirms the goodness of the natural order but also because it asserts that God relates to us immanently in a sacramental and incarnational way through material reality. ${ }^{19}$ In this sense, the notion of real presence allows us to draw closer to God through our association with Jesus. According to Brown, the "divine nature in Christ renders his body incorruptible and so through association with that body our own too could achieve a similar status" (Brown 2007, p. 409). In a similar statement, he writes that "Christ's humanity is envisaged as coming close in order to create Christ-like beings in their own distinctive context" (Brown 2007, p. 419). By identifying with the body of Christ as real presence in the Eucharist, we can cultivate the understanding that God is still with us making the

18 Concerning the continued widespread view of a literalist interpretation of the Eucharistic sacrifice of Christ, Macquarrie writes the following: "In spite of St. Thomas' attempt to construct a reasonable account of transubstantiation, one which should have put an end to the crudely materialistic interpretations that were going around, superstitious ideas continued to gain ground." See (Macquarrie 1997, p. 129).

19 In brief, Brown argues for a broadened notion of sacramentality in which God is understood to be sacramentally present in all aspects of human culture and the entire natural world. For a description of the framework of his sacramental theology, see, in particular (Brown 2004, chp. 1). 
divine presence known in the lives we are living in our necessarily ecological context. In brief, our imaginative association with Christ's bodily presence strengthens our sacramental connection to the loving grace of God that is ever available to us if we will only take the time to foster an awareness of its presence. $^{20}$

Of course, locating the real divine presence in the Eucharist is not an empirical proposition. Instead, it is an orientation to life, a life that can be understood to be infused with value, meaning, and purpose in a sacramental universe. Brown describes this as follows:

To state the obvious, whatever Christ's present body is like, it cannot be literally material, as though with sufficient progress in science we might one day be able to reach where it is now. Its nature has somehow to be reconciled with the fact that heaven, God's dwelling place, is a non-material reality and indeed omnipresent, just as God is ... Yet none of this should be taken to indicate the abandonment of any notion of some degree of equivalence to material reality. (Brown 2007, p. 408)

Such an understanding is connected with the perspective that the grace conveyed through the Eucharist is, in fact, a mystery. Therefore, Brown's understanding of the bodily presence of Christ with which we identify in the Eucharist is not subject to empirical verification but is instead a mysterious presence that potentially points us toward an orientation that we, as embodied creatures, receive the grace of God through the substances of the world in which we exist and not through an ethereal or supernatural reality.

This may seem to place the understanding of real Eucharistic presence at odds with a scientific worldview. However, I would argue that the same sense of mystery that connects us to a larger presence of grace in the world through our participation in the Eucharist is the same sense that helps us value our kinship with all of life on Earth through an awareness of the Epic of Evolution. Consider Bruce Morrill's description of the place of mystery in the Eucharist:

The word mystery ... is not meant to hinder believers' use of reason and imagination as they seek a greater appreciation and joy in celebrating the Eucharist. Rather, to speak of the Eucharist as mystery is to acknowledge at the outset the complexity of our inquiry, and this not as a forbidding caution but a promising invitation. In fact, "mystery" was the preferred term of the earliest Christians for referring not only to the Eucharist and baptism but to all concrete ways in which they experienced God entering into and shaping their lives in Christ. (Morrill 2012, p. 1)

An acceptance of mystery of this kind is not a willful ignorance of scientific theory but is instead a profound respect for and faith in the source and sustenance of the lives we are blessed to live, a knowledge of which, we have to admit, is not completely known from our human perspective.

To further this point, it is instructive to compare this with the explanation of mystery from Bron Taylor who accepts the evolutionary and ecological history of life on Earth as the primary source of religious inspiration. Referencing environmentalist Loren Eiseley, he writes:

With Loren Eiseley, I am convinced that the theory of evolution is the best explanation for the beauty, diversity, and fecundity of the biosphere. I also agree with him that nothing in the world fully explains the world. As he puts it, "I am an evolutionist ... [but] in the world there is nothing to explain the world. Nothing to explain the necessity of life, nothing to explain the hunger of the elements to become life, nothing to explain why the stolid realm of rock and soil

20 The use of the term 'imaginative' is a reference to Brown's Tradition and Imagination: Revelation and Change in which Brown uses 'imagination' as an interpretive term to argue that we should not separate revelation and tradition in theological discourse as if Biblical revelation holds a monopoly on definitive divine revelation. Furthermore, tradition is understood to be an ever-emergent process focused on interpreting the ongoing revelation of God in the world. See (Brown 1999). 
and mineral should diversify itself into beauty, terror, and uncertainty." This humble admission captures, I think, the idea that the universe is a Great Mystery. (Taylor 2010, p. 220)

A willingness to accept a sense of mystery in life demonstrates a humility that is often lacking in both religious and scientific inquiry. ${ }^{21}$ By accepting the real presence of the divine, incarnate in Christ in the Eucharist, we are, in a sense, opening ourselves to the broader mysteries of life that surround us, which, when properly understood, can also reflect to us the saving grace of God through an understanding of ecological grace in a sacramental universe.

\section{Christ, the Primordial Sacrament in a Sacramental Universe}

At this point, I want to take a closer look at how the mysterious bodily presence of Christ in the Eucharist can potentially connect the sacramental grace recognized in the formal ritual worship of the church with the larger sacramental universe in which it exists. I will begin with Edward Schillebeeckx's notion of Christ as the "primordial sacrament."

In the early 1960s, Schillebeeckx published Christ, the Sacrament of the Encounter with God in which he argues that "the sacraments are the properly human mode of encounter with God" and, furthermore, that "Jesus, as the personal visible realization of the divine grace of redemption, is the sacrament, the primordial sacrament" (Schillebeeckx 1963, pp. 6, 15). For Schillebeeckx, the sacraments continue the promise of the incarnation in that they serve as "the face of redemption turned visibly towards us, so that in them we are truly able to encounter the living Christ" (Schillebeeckx 1963, pp. 43-44). Consequently, because God is Emmanuel, "God with us" in an incarnational way through the sacraments, he claims that a "permanent sacramentality is thus an intrinsic requirement of the Christian religion" (Schillebeeckx 1963, p. 44).

The Eucharist, in particular, serves as the material expression of Christ's bodily presence in the world. Schillebeeckx describes the primordial sacrament of Christ as a stone thrown into a pond with the ripples flowing outward in concentric circles of grace from its central point of connection with the Eucharist serving as the central sacramental activity from which grace flows: "The sacrament of the Eucharist is situated at the heart of this central point-the Eucharist is the focal point of Christ's real presence among us. Around this focal point can be seen the first radiant lights-the other six sacraments" (Schillebeeckx 1963, p. 215). He adds that these "sacramental ripples ... continue to spread still further, though they gradually become less and less clearly defined-at this stage they are the sacramentals" (Schillebeeckx 1963, p. 215). In other words, the real presence of Christ in the Eucharist extends beyond the formal practice of the sacrament itself and into the world with an emanating grace that is the source of a broader sacramentality. ${ }^{22}$

In Hymn of the Universe, the Jesuit paleontologist Pierre Teilhard de Chardin offers a vivid demonstration of this idea. He relates a story in which, while observing the host, it began "gradually spreading out like a spot of oil but of course much more swiftly and luminously" (Teilhard de Chardin 1965, p. 47). Continuing, he states that "through the mysterious expansion of the host the whole world had become incandescent, had itself become like a single giant host" (Teilhard de Chardin 1965, p. 48). In this example, it is the host itself as the physical embodiment of

21 As referenced at the beginning of this paper, E.O. Wilson is given credit with coining the term 'Epic of Evolution,' and it is worth noting that he implies a sense of mystery in the scientific understanding of life when he writes that the evolutionary epic "can be adjusted until it comes as close to truth as the human mind is constructed to judge the truth." See (Wilson 1978, p. 201).

22 In discussing the extension of Eucharistic grace into a wider sacramental universe, we must not forget the understanding of the cosmic dimension of the Eucharist itself. While it points outward toward a broader sense of sacramentality, it also represents, in microcosm, the macrocosm of all of God's continuing creation. Take, for instance, the following statement from Alexander Schmemann: "In the eucharist, the commemoration is the gathering together of the entire experience of salvation, the entire fullness of that reality that is given us in the Church and that constitutes our life. It is the reality of the world as God's creation, the reality of the world as saved by Christ, the reality of the new heaven and the new earth, to which we ascend in the sacrament of ascension to the kingdom of God." See (Schmemann 1987, p. 221). 
the presence of Christ on Earth that reaches out to touch the universe from which all life has emerged, bringing us with it into a greater realization of the immensity of divine creativity. Reflecting upon this experience, Teilhard de Chardin writes:

[M]y mind awoke to a new and higher vision of things. I began to realize vaguely that the multiplicity of evolutions into which the world-process seems to us to be split up is in fact fundamentally the working out of one single great mystery; and this first glimpse of light caused me ... to tremble in the depths of my soul. But I was so accustomed to separating reality into different planes and categories of thought that I soon found myself lost in this spectacle, still new and strange to my tyro mind, of a cosmos in which the dimensions of divine reality, of spirit, and of matter were also intimately mingled. (Teilhard de Chardin 1965, p. 50)

In a similar, recent example, Catherine Vincie applies this extension of the real presence of the Eucharist to our expanding knowledge in the areas of ecological and evolutionary biology and cosmological physics that serve as the foundation of the Epic of Evolution as well as to our contemporary pluralistic context in which Christian sacramental life exists: “We must expand our imaginations to include in the communion of Christ those of other faith traditions and those who are not believers, as well as the community of Earth and the billions of galaxies that fill our skies. Christ is the Alpha of the universe; he is the new beginning, not the end" (Vincie 2014, p. 91). Vincie's placement of this conversation within the increasingly pluralistic cultures in which Christianity is practiced in many parts of the world is important since we must be cognizant of and humble enough to admit that Christian worship does not provide the exclusive means to access this sacramentality. As Sallie McFague points out, an ecological Christology should avoid falling into "Jesusolatry" by recognizing that "Jesus is the finger pointing to the moon" (McFague 2000, p. 34).

I would like to suggest that the Christian community can resist such exclusivist temptations when applying the Eucharist to an understanding that we live in a sacramental universe by recognizing that the presence of God that is revealed in a unique way in the life of Jesus is the same God who is still present with us, Christian and non-Christian, religious and non-religious. Stated in a slightly different way, the divine source of the universe and the life that has emerged and is still emerging from it is the same source of grace that was present in the life of Jesus. This sacramental grace can be experienced and embraced regardless of one's religious affiliation, and, I would argue even further, regardless of whether one is a theist or non-theist. I do not think that it is difficult to accept that the grace of God is present to all living things whether we realize it or not and also that this grace does not depend on human recognition for it to be efficacious. As Christians, we can acknowledge and accept the potential validity of other worldviews while maintaining the commitment that we are oriented to this presence sacramentally through our association with the bodily incarnation of God in Jesus. The historical centrality in Christian tradition of the life and revelation of God in Jesus connects Christian worshippers through Eucharistic practice to a potential encounter with the real presence of the divine in all things, a presence that binds everything that exists together in a vast interconnected divine embrace.

If we take such an understanding of the incarnation and its implications for a sacramental universe filled with ecological grace seriously, then everything is capable of having sacramental value. From a Christian perspective, this is not in addition to but as a result of our understanding that God became incarnate in the person of Jesus Christ. In his description of the host that expanded to include all of creation, Teilhard de Chardin adds that "in actual fact the immense host, having given life to everything and purified everything, was now slowly contracting; and the treasures it was drawing into itself were joyously pressed together within its living light" (Teilhard de Chardin 1965, p. 49). I think that Teilhard de Chardin's mystical vision is illustrative of how the sacramental worship of the Eucharist relates to the expanded sacramentality of a sacramental universe. Our experience of the real presence in the substances of the bread and wine received in the Eucharist expands our awareness of God's grace in all of the natural world. Yet, the Eucharist does not have an outward trajectory alone as it continuously draws us back in as a community of the faithful to glorify the gifts of creation in worship and to 
experience the mysterious presence of Christ so that we can be returned again and again into the wider world with the reminder that God is Emmanuel, "God with us," in order to emulate the self-giving sacrifice of Jesus in the lives we lead in our cultural and ecological communities.

Bernard Cooke relates the sacrifice of Christ in the Eucharist to the self-giving action of Jesus in which we are called to participate. In his words, this "means that the risen Christ is giving himself in new life to his friends. This self-giving by the risen Lord is his continuing action of 'offering sacrifice.' And the corollary of this is that Christians' action of 'offering sacrifice' consists in their loving self-gift to their fellow humans." Therefore, according to Cooke, "what the eucharist celebrates is that the entire life of these Christians, if lived out in loving concern for and genuine self-gift to their fellow humans, is a living sacrifice (Cooke 1994, pp. 112-13)." The mention here of self-giving and life is very important as it opens us up to a life of loving relationship with others, which, as Cooke points out, includes our fellow humans, but for the purpose of this essay, I would like to insist that this self-giving sacrifice can be extended to include all of God's ongoing Creation. This extension is implicit in Schillebeeckx's claim of a permanent sacramentality emanating outward from the Eucharist to the less-defined sacramentals of the wider world. It is also more explicitly evident in Brown's connection of incarnational presence, which is available in the Eucharist, to the concept of immanence: "So for God to impact on every aspect of us immanence must also be claimed: God involved in matter. Christians believe that this happened at the deepest and most profound level in the incarnation, but if there is to be a continuing effect this cannot have happened just once, but must relate to all material existence" (Brown 2004, pp. 81-82). The implication is that one's neighbors are not human alone but extend to the entire community of life an awareness of which can be sacramentally cultivated through participation in the thanksgiving of the Eucharistic meal.

\section{Conclusions}

Schubert Ogden maintains that all Christian theological claims must abide by the criteria of appropriateness and credibility (Ogden 1986, pp. 4-5). According to Ogden, Christian theology must be appropriate in the sense that it simultaneously accepts a connection to the tradition of which it is inextricably a part and to the contemporary context in which we live our lives. The Epic of Evolution compels us to look backward to our natural history for the purpose of understanding where we came from and who we are in our contemporary context so that we may value and protect the Earth's ecology as we go forward. The Eucharistic sacrament, while firmly rooted in Christian tradition, has the potential to significantly contribute to this backward and forward perspective by orienting us toward the recognition of sacramental grace present in the ongoing evolutionary epic. From this perspective, the Christian sacramental tradition can be understood as distinct but inseparably related to a broader understanding of sacramentality in which God's grace can be potentially witnessed, understood, and valued in all aspects of the natural world. As we come to the Eucharistic table, we humbly embrace life in all of its uncertainty, joy, sorrow, complexity, and beauty by fully immersing ourselves in sacramental worship so that we may come to reverence and protect God's ongoing Creation, what Wilson refers to as "Living Nature," the source of all grace and value. ${ }^{23}$ Recognizing the power of religious and scientific narratives in our time, Wilson claims that, "[i]f religion and science could be united on the common ground of biological conservation, the problem would soon be solved" (Wilson 2007, p. 5). I propose that a deeper exploration of the ecological significance of sacramental theology is a step in the right direction.

Of course, there will be other interpretations of the Eucharist that continue to exist in Christian theological discourse, some of them more compatible with the scientific view of the Epic of Evolution and others less so. However, I would argue that a Eucharistic theology of ecological grace is an

23 Wilson uses the theological language of "the Creation," defined by him as "living Nature," to bring science and religion together for the purpose of protecting biodiversity. See (Wilson 2007, p. 4). 
appropriate and credible expression of Christian tradition. It maintains the perspective that the Eucharist serves as our primary orientation to sacramental grace without, on the one hand, distorting the tradition in order to cohere with the narrative of the Epic of Evolution or, on the other, allowing the tradition to distort a proper understanding of the ecological and evolutionary process of life from which we emerged and upon which we depend for our continued sustenance. Furthermore, a proper understanding of the tradition of Eucharistic practice makes it clear that the trajectory of the Eucharist is such that it can reach out to heal not only human communities but also to alleviate the degradation of all life on Earth.

It is my opinion that the very heart of Christian faith, worship, and theology is predicated on Jesus' claim in the Synoptic gospels that the greatest commandments are loving God and loving one's neighbor as oneself. ${ }^{24}$ If one interprets these commandments sacramentally, then they are best understood not as separate commandments but instead as the second fulfilling the first. In other words, we love God by loving life which only exists for us in embodiment. Furthermore, the emphasis of Jesus' life and teaching as it has been passed down to us in tradition makes it clear that what constitutes our neighbor should be characterized by an ever-widening circle. It is not difficult to imagine that circle widening further to include, in the words of American environmentalist Aldo Leopold, "the integrity, stability, and beauty of the biotic community." 25 Therefore, the implications for loving God through love of neighbor in this manner are that all of life becomes a form of sacramental worship.

This greatest of all commandments intimately links us with the life of Jesus in being responsible, as humans, for offering our own self-giving sacrifice in the lives we lead for the fulfillment of the potential of God's ever-present grace in the evolving divine creation. Furthermore, our experience of the incarnation of Jesus embodied in the Eucharist can be lived out in Christian life by following Jesus' "way" of selfless love for God through love of neighbor. Morrill grounds the Eucharistic liturgy in the story of the road to Emmaus from the Gospel of Luke where the disciples only become aware of the identity of the risen Jesus following the breaking of bread in a ritual meal (Morrill 2012, pp. 9-11). He describes the significance of this foundational story as follows: "In light of the sacramental action, the full force of the word the Lord had proclaimed in their company sets their hearts blazing and their feet back on the road. Only now, however, they hit the road with purpose, the mission of bringing the message of Christ crucified to life for the world" (Morrill 2012, p. 10). This experience is available to us as well each time we approach the Eucharistic table to acknowledge the beautiful mystery that a real divine presence infuses all of life and that life continues to emerge from death as the evolutionary epic continues on, perpetuating ecological value through the loving grace of God in a sacramental universe. Embracing such a Eucharistic theology of ecological grace allows us to give thanks for this gift of life by glorifying God through the preservation of the evolving sacramental ecology from which all life emerges.

Funding: This research received no external funding.

Conflicts of Interest: The author declares no conflict of interest.

\section{References}

Book of Common Prayer. 2007. New York: Church Publishing Incorporated.

Bradshaw, Paul F., and Maxwell Johnson. 2012. The Eucharistic Liturgies: Their Evolution and Interpretation. Collegeville: Liturgical Press.

Brown, David. 1999. Tradition and Imagination: Revelation and Change. New York: Oxford University Press.

Brown, David. 2004. God and Enchantment of Place: Reclaiming Human Experience. New York: Oxford University Press.

24 See Matthew 22:35-40, Mark 12:28-31, Luke 10:25-28.

25 In his A Sand County Almanac, Aldo Leopold famously wrote that a "thing is right when it tends to preserve the integrity, stability, and beauty of the biotic community. It is wrong when it tends otherwise." See (Leopold 1968, pp. 224-25). 
Brown, David. 2007. God and Grace of Body: Sacrament in Ordinary. New York: Oxford University Press.

Cooke, Bernard. 1994. Sacraments and Sacramentality. Mystic: Twenty-Third Publications.

Darwin, Charles. 2006. From so Simple a Beginning: The Four Great Books of Charles Darwin. New York: W. W. Norton \& Company.

Leopold, Aldo. 1968. A Sand County Almanac and Sketches Here and There. New York: Oxford University Press. Macquarrie, John. 1997. A Guide to the Sacraments. New York: Continuum.

McFague, Sallie. 2000. An Ecological Christology: Does Christianity Have it? In Christianity and Ecology: Seeking the Well-Being of Earth and Humans. Edited by Dieter T. Hessel and Rosemary Radford Ruether. Cambridge: Harvard University Press, pp. 29-45.

Morrill, Bruce T. 2012. Encountering Christ in the Eucharist: The Paschal Mystery in People, Word, and Sacrament. New York: Paulist Press.

Ogden, Schubert M. 1986. On Theology. San Francisco: Harper and Row Publishers.

Saliers, Don E. 1994. Worship as Theology: Foretaste of Glory Divine. Nashville: Abingdon Press.

Schillebeeckx, Edward. 1963. Christ the Sacrament of the Encounter with God. New York: Sheed and Ward.

Schmemann, Alexander. 1987. The Eucharist: Sacrament of the Kingdom. Crestwood: St. Vladimir's Seminary Press. Taylor, Bron. 2010. Dark Green Religion: Nature Spirituality and the Planetary Future. Berkeley: University of California Press.

Teilhard de Chardin, Pierre. 1965. Hymn of the Universe. New York: Harper and Row, Publishers.

Temple, William. 1951. Nature, Man, and God. London: MacMillan and Company, Limited.

The Green Bible. 2008. The Green Bible (New Revised Standard Version). New York: HarperCollins Publishers.

Vincie, Catherine. 2014. Worship and the New Cosmology: Liturgical and Theological Challenges. Collegeville: Liturgical Press.

Wilson, Edward O. 1978. On Human Nature. Cambridge: Harvard University Press.

Wilson, Edward O. 1984. Biophilia. Cambridge: Harvard University Press.

Wilson, Edward O. 1999. Consilience: The Unity of Knowledge. New York: Vintage Books.

Wilson, Edward O. 2002. The Future of Life. New York: Vintage Books.

Wilson, Edward O. 2006. Naturalist. Washington: Island Press.

Wilson, Edward O. 2007. The Creation: An Appeal to Save Life on Earth. New York: W. W. Norton \& Company.

Wilson, Edward O. 2012. The Social Conquest of Earth. New York: W. W. Norton \& Company.

(C) 2019 by the author. Licensee MDPI, Basel, Switzerland. This article is an open access article distributed under the terms and conditions of the Creative Commons Attribution (CC BY) license (http://creativecommons.org/licenses/by/4.0/). 